\title{
Państwowe Muzeum Zoologiczne wobec powstania Polskiej Akademii Nauk: droga do powołania Instytutu Zoologicznego PAN
}

\author{
The State Zoological Museum and the Establishment \\ of the Polish Academy of Sciences: The Beginnings \\ of the Institute of Zoology of the Polish Academy \\ of Sciences
}

The State Zoological Museum, established in 1928, inherited and developed the legacy of the Zoological Cabinet of the University of Warsaw (existing since 1818). The Cabinet's collection had been gathered for decades and belonged to eminent personages not only in Poland but also in Europe. The Museum and its collections were threatened many times: first by a great fire in 1935, then by the German attack on Warsaw in 1939 and subsequent occupation, as well as by the outbreak of the Warsaw Uprising and the destruction of the city. After the post-war reconstruction of the Museum, it was time to function in a new political reality, in which the most significant change for this institution was the establishment of the Polish Academy of Sciences. A planned inclusion of the State Zoological Museum in the structures of the newly-founded Polish Academy of Sciences meant that the scientists had to face a dilemma: in exchange for research funds and career development opportunities, they were expected to show favour to the communists and readiness to implement the idea of socialism. In the background of this process, numerous scientific conferences took place, where controversial visions of the future of biological sciences clashed. This process resulted in the transformation of the State Zoological Museum into the Institute of Zoology of the Polish Academy of Sciences.

Keywords: State Zoological Museum, Zoological Cabinet, Polish Academy of Sciences, Institute of Zoology, National Natural History Museum, Congress of Polish Science, Polish Academy of Arts and Sciences, Warsaw Scientific Society, 'new biology'

Słowa kluczowe: Państwowe Muzeum Zoologiczne, Gabinet Zoologiczny, Polska Akademia Nauk, Instytut Zoologiczny, Narodowe Muzeum Przyrodnicze, Kongres Nauki Polskiej, Polska Akademia Umiejętności, Towarzystwo Naukowe Warszawskie, „nowa biologia” 
Państwowe Muzeum Zoologiczne powołane zostało 29 lutego 1928 r. rozporządzeniem Prezydenta RP Ignacego Mościckiego ${ }^{1}$ z przekształcenia kolejnych centralnych polskich instytucji przyrodniczych, będących spadkobiercami dziedzictwa istniejącego od 1818 r. Gabinetu Zoologicznego Uniwersytetu Warszawskiego ${ }^{2}$. Kolekcje Gabinetu zbierane były przez dziesięciolecia, a ich ważną część stanowiły zakupione lub przekazane do Muzeum cenne kolekcje prywatne - w tym m.in. eksponaty ze zbiorów: Silviusa Augusta Minckwitza (1772-1818), Alojzego Estreichera (1786-1852), Władysława Taczanowskiego (1819-1890), Konstantego Branickiego (1824-1884) i jego syna Ksawerego (1864-1926), czy Benedykta Dybowskiego (1833-1930). Zbiory zoologiczne instytucji już w połowie XIX w. należały do największych na ziemiach polskich - dla przykładu, samych tylko okazów ornitologicznych było więcej niż łącznie we wszystkich innych zbiorach krajowych ${ }^{3}$. Bogate były również m.in. kolekcje syberyjska i neotropikalna, a także zbiory entomologiczne. Kolekcja dynamicznie rosła i była liczącym się w Europie zbiorem fauny z całego świata, a liczba okazów w Muzeum pod koniec lat trzydziestych XX w. liczyła już kilka milionów ${ }^{4}$.

Siedzibą Gabinetu od 1818 r. był Pałac Kazimierzowski5', a następnie, od 1823 r., uniwersytecki budynek Pawilonu Sztuk Pięknych na kampusie głównym przy Krakowskim Przedmieściu6, gdzie Gabinet, a następnie jego kontynuatorzy, mieścili się do 1935 r., kiedy w Muzeum wybuchł wielki pożar. Katastrofa ta nie tylko spowodowała zniszczenie tysięcy okazów zoologicznych, setek ksiąg i sprzętu naukowego7, lecz również zmusiła rząd do znalezienia dla instytucji nowej siedziby, którą z założenia tymczasowo stał się budynek dawnej szkoły przy ul. Wilczej 64 w Warszawie.

Zarówno w poprzedniej, jak i nowej siedzibie Muzeum borykało się z dużymi problemami lokalowymi, brakowało przestrzeni do pracy naukowej oraz sal do eksponowania

1 Rozporządzenie Prezydenta Rzeczpospolitej z dnia 29 lutego 1928 r. o Państwowem Muzeum Zoologicznem, Dziennik Ustaw poz. 207 i 208, nr 24.

2 Pierwszą stworzoną po odzyskaniu niepodległości instytucją przyrodniczą, wydzieloną z Uniwersytetu Warszawskiego, było Narodowe Muzeum Przyrodniczego w Warszawie (powołane rozporządzeniem Ministra Wyznań Religijnych i Oświecenia Publicznego Jana Łukasiewicza z 24 IX 1919 r.). Nazwa nowej instytucji przyrodniczej powodowała liczne nieporozumienia ze względu na funkcjonowanie w Warszawie miejskiego Muzeum Narodowego, dlatego na wniosek dyrekcji Narodowego Muzeum Przyrodniczego Minister Wyznań Religijnych i Oświecenia Publicznego Maciej Rataj wydał 7 IX 1921 r. rozporządzenie zmieniające wcześniejszą nazwę instytucji na Polskie Państwowe Muzeum Przyrodnicze. Pod tą nazwą jednostka działała do 29 II 1928 r., kiedy powołano Państwowe Muzeum Zoologiczne.

3 150-lecie Gabinetu Zoologicznego w Warszawie (1818-1968), [w:] Memorabilia Zoologica, red. D. Iwan, Warszawa 2016, s. 26.

4 Dokładna liczba okazów nie jest znana, bowiem PMZ nie prowadziło wtedy całościowych spisów kolekcji, niemniej z raportów Stanisława Feliksiaka ze strat wojennych wynika, że w 1939 r. w Muzeum było co najmniej 4 miliony okazów przyrodniczych. Zob. P. Daszkiewicz, D. Iwan, Straty wojenne Państwowego Muzeum Zoologicznego - raport Stanisława Feliksiaka (1906-1992), „Pamięć i Sprawiedliwość. Pismo Instytutu Pamięci Narodowej" t. 27, 2016, s. 431-439.

5 T. Majewski, Nauki biologiczne, [w:] Nauki ścisłe i przyrodnicze na Uniwersytecie Warszawskim, red. A.K. Wróblewski, Warszawa 2016, s. 59.

6 Od 1938 r. budynek jest siedzibą Instytutu Historycznego UW.

7 Archiwum Muzeum i Instytutu Zoologii PAN [AMilZ], sygn. A 166, J. Domaniewski, Sprawozdanie ze strat w Bibljotece spowodowanych pożarem Państwowego Muzeum Zoologicznego w Warszawie w dniu 1-ym października 1935 roku. W sprawozdaniu Domaniewski podaje jedynie przybliżone dane o stratach, jak bowiem przyznał w piśmie przewodnim do Wydziału Nauki i Sztuki Ministerstwa Wyznań Religijnych Oświecenia Publicznego, do którego załączył Sprawozdanie: „Dokładny wykaz spalonych obiektów nie jest możliwy do przeprowadzenia, a to dlatego, że inwentaryzacja zbiorów Muzeum nie była przeprowadzona przez Muzeum, a księgi inwentarzowe, obejmujące część spisanych zbiorów, spaliły się w czasie pożaru". 
i przechowywania okazów ${ }^{8}$. Gmach przy ul. Wilczej zaadoptowano bez wcześniejszego wykonania niezbędnych remontów, chociaż stan budynku od początku opisywano jako fatalny. Z projektu budżetu Państwowego Muzeum Zoologicznego z przełomu lat 1936 i $1937^{9}$ wiadomo, że roczny plan finansowy instytucji stanowił wtedy nieco ponad 162 tys. zł, co pozwalało na zatrudnienie zaledwie 15 pracowników naukowych ${ }^{10}$. Kolejni dyrektorzy Muzeum skarżyli się z tego powodu na bardzo małe budżety, ograniczenie rozwoju badań, brak środków na wyprawy naukowe, sprzęt badawczy, konieczność oszczędzania na zakupie wydawnictw zagranicznych, a nawet na kopertach i znaczkach pocztowych.

W następnych latach budżet Muzeum nieco zwiększano, a liczba personelu wzrastała ${ }^{11}$. Jednocześnie planowano budowę nowego gmachu o powierzchni użytkowej $6000 \mathrm{~m}^{2}$ według projektu architekta prof. Stefana Tworkowskiego (1907-1995). Plany te przerwał jednak wybuch wojny.

W czasie niemieckiego ataku na Warszawę w 1939 r. budynek Muzeum został uszkodzony, niemniej, jak w powojennej notatce ocenił były kierownik instytucji Kazimierz Tarwid $^{12}$, „z oblężenia Warszawy Muzeum wyszło obronną ręką"13. Większe straty spowodowała późniejsza akcja grabieży zbiorów PMZ przez oddział SS - Sonderkommando Paulsen, który zjawił się w gmachu Muzeum w listopadzie 1939 r. i wywiózł do III Rzeszy, głównie austriackiego Salzburga, cztery ciężarówki cennych zbiorów ${ }^{14}$.

Na przełomie 1939/40 r. nadzór na Muzeum przejęła niemiecka administracja w postaci Komisji Likwidacyjnej Ministerstwa Wyznań Religijnych i Oświecenia Publicznego (niem. Die Abwicklungsstelle fur dasehemalige Polnische Kultur und Unterrichtsministerium), która najpierw zakazała wpuszczania byłych pracowników do Muzeum, a później nieco złagodziła reguły, godząc się na konserwację zbiorów przy podtrzymaniu zakazu pracy naukowej. Opiekunami zbiorów byli w tym czasie: mgr Władysław Rydzewski ${ }^{15}$ (do lipca 1940 r.),

8 Przy Krakowskim Przedmieściu Muzeum dysponowało $1394 \mathrm{~m}^{2}$, przy ul. Wilczej 1365m², zob. 150-lecie Gabinetu Zoologicznego, s. 38.

9 AMilZ, sygn. A 144, Projekt Budżetu Państwowego Muzeum Zoologicznego od 1 kwietnia 1936 do 31 marca 1937.

10 Ówczesny dyrektor Państwowego Muzeum Zoologicznego, prof. Wacław Roszkowski, oceniał potrzeby kadrowe jednostki na co najmniej 27 pracowników naukowych, zob. ibid., s. 2.

11 W sierpniu 1939 r. liczba pracowników Muzeum wzrosła do 37, łącznie z personelem administracyjnym i korespondentami i wolontariuszami, zob. 150-lecie Gabinetu Zoologicznego, s. 39.

12 Kazimierz Tarwid (1909-1988), polski biolog (ekolog), związany z Uniwersytetem Warszawskim (od 1954 r. profesor nadzwyczajny) i Państwowym Muzeum Zoologicznym (kierownik w latach 1940--1944), żołnierz Armii Krajowej i uczestnik powstania warszawskiego, zob. Muzeum Powstania Warszawskiego, Powstańcze Biogramy, 1944.pl/powstancze-biogramy/kazimierz-tarwid,45736.html [dostęp 15.03.2020].

13 AMilZ, sygn. A 2257, K. Tarwid, Zbiory przyrodnicze $i$ ich losy w Warszawie, s. 2. Dokument powojenny, niedatowany.

14 Akcją rabunkową kierował ówczesny dyrektor Museum der Natur w Salzburgu Eduard Paul Tratz. Celem grabieży były okazy przyrodnicze (m.in. czaszki turów i nosorożca kopalnego i dwa żubry, trofea myśliwskie), książki, meble i sprzęt optyczny, zob. 150-lecie Gabinetu Zoologicznego, s. 40. Akcja odbyła się w ramach szerokich działań rabunkowych specjalnego oddziału SS - Sonderkommando Paulsen, którym kierował profesor archeologii, oficer SS i członek NSDAP Peter Paulsen, zob. E. Klee, Das Personenlexikonzum Dritten Reich, Frankfurt nad Menem 2007, s. 452.

15 Władysław Rydzewski (1911-1980), polski zoolog (ornitolog), pracownik Państwowego Muzeum Zoologicznego, gdzie od 1936 r. kierował Stacją Badania Wędrówek Ptaków. W czasie wojny w Związku Walki Zbrojnej, potem w Armii Krajowej, uczestnik powstania warszawskiego odznaczony za męstwo orderem Virtuti Militari. Później w Polskich Siłach Zbrojnych na Zachodzie, a po wojnie na emigracji w Londynie. W 1960 r. powrócił do Polski, gdzie został kierownikiem Muzeum Zoologicznego przy Instytucie Zoologicznym Uniwersytetu Wrocławskiego. Później m.in. przewodniczący Rady Naukowej Instytutu Zoologicznego PAN w Warszawie. Zob. J.A. Czyżewski, Rydzewski Władysław, [w:] Słownik biologów polskich, red. S. Feliksiak, Warszawa 1987, s. 464-465. 
a po nim mgr Kazimierz Tarwid (do października 1944 r.). Zbiory Muzeum udało się ocalić wtedy tylko dzięki ofiarności byłego personelu Muzeum i wsparciu wolontariuszy ${ }^{16}$.

Kolejną próbą dla Państwowego Muzeum Zoologicznego, jego pracowników i zbiorów był wybuch powstania warszawskiego. W walkach wyzwoleńczych wzięli udział pracownicy Muzeum, wśród nich m.in.: dr Tadeusz Jaczewski ${ }^{17}$, dr Stanisław Feliksiak ${ }^{18}$, mgr Władysław Rydzewski i mgr Stanisław Adamczewski ${ }^{19}$. Szczęśliwie straty materialne Muzeum podczas powstania oceniano jako minimalne, a Kazimierz Tarwid wymienił zaledwie: „kilkanaście rozbitych przez kule gablot i słojów własnych, oraz kilkadziesiąt słojów depozytu uniwersyteckiego"20. Prawdziwy dramat przyszedł jednak po upadku zrywu, gdy Niemcy rozpoczęli akcję równania Warszawy z ziemią, a samo Muzeum pozostało bez jakiejkolwiek opieki. Misji ratowania zbiorów podjęli się wtedy pracownicy PMz, którzy przy wsparciu Komitetu Ewakuacji Mienia Kulturalnego z Warszawy brali udział w nielegalnych i śmiertelnie niebezpiecznych wypadach do miasta ${ }^{21}$. 12 października 1944 r. Stanisław Feliksiak i Stanisław Adamczewski dotarli na ul. Wilczą, ugasili płonące części gmachu i zaczęli zabezpieczać zbiory, dokumenty i cenniejsze materiały ${ }^{22}$. Jak podaje Kazimierz Tarwid $^{23}$, podjęto następnie ogromne wysiłki aby zabezpieczyć i wywieźć z Muzeum możliwie wielką ilość zbiorów, podłączając się pod akcję ewakuacji dóbr kultury z Warszawy. Skutkiem akcji było zabezpieczenie tysięcy okazów na Wilczej 64 oraz ewakuacja pociągami do Piotrkowa trzech dziesięciotonowych wagonów kolejowych ładunku. Pomimo ofiarnych działań ratunkowych straty Muzeum były gigantyczne. W sprawozdaniu z 25 lutego 1945 r. ${ }^{24}$ Stanisław Feliksiak ocenił, że na dzień 5 listopada 1944 r. ogół zniszczeń wojennych w Państwowym Muzeum Zoologicznym wyniósł 43,5\%. Kompletnemu zniszczeniu uległy urządzenia wszystkich pracowni, archiwów i sekretariatu. Spalone zostały zbiory entomologiczne z całego świata obejmujące blisko 2 mln okazów.

Wznowienie działalności Muzeum nastąpiło 19 stycznia 1945 r. Instytucją kierował dr Stanisław Feliksiak, którego osobiste dobre kontakty z pułkownikiem Marianem Spychalskim ${ }^{25}$

16 150-lecie Gabinetu Zoologicznego, op. cit., s. 41.

17 Tadeusz Jaczewski (1899-1974), polski zoolog (hemipterolog), profesor Uniwersytetu Warszawskiego, w latach 1924-1939 kustosz w Państwowym Muzeum Zoologicznym, członek Towarzystwa Naukowego Warszawskiego. W latach 1953-1958 dyrektor Instytutu Zoologii PAN. Zob. K. Kowalski, Jaczewski Franciszek Antoni (1899-1974), [w:] Słownik biologów polskich, s. 220-221.

18 Stanisław Feliksiak (1906-1992), polski zoolog (malakolog), w 1938 r. uzyskał doktorat, a w 1953 r. profesurę na Uniwersytecie Warszawskim. W latach 1945-1953 kierownik, a następnie (od 1947 r.) dyrektor Państwowego Muzeum Zoologicznego, członek Towarzystwa Naukowego Warszawskiego. Zob.150-lecie Gabinetu Zoologicznego, s. 45.

19 Stanisław Franciszek Adamczewski (1909-1987), polski entomolog (lepidopterolog), późniejszy profesor nauk biologicznych (doktorat 1950, profesura nadzwyczajna 1954 - na Uniwersytecie Marii Skłodowskiej-Curie w Lublinie), związany z Państwowym Muzeum Zoologicznym, potem Instytutem Zoologii Polskiej Akademii Nauk. Zob. G. Winiarska, Adamczewski Stanisław Franciszek, [w:] Almanach Entomologów Polskich XX wieku, red. M. Bunalski, J.J. Lipa, J. Nawacki, Poznań 2001, s. 18.

20 AMilZ, sygn. A 2257, s. 3.

21 150-lecie Gabinetu Zoologicznego, s. 42-43.

22 Ibid.

23 AMilZ, sygn. A 2257, s. 3.

24 AMilZ, sygn. A 2256, Memoriał Stanisława Feliksiaka w sprawie Państwowego Muzeum Zoologicznego w Warszawie sporządzony 25 lutego 1945 roku w Lublinie.

25 W swoich wspomnieniach Feliksak pisał o „życzliwej postawie i aktywnej pomocy” Spychalskiego w sprawie odbudowy Muzeum (zob. 150-lecie Gabinetu Zoologicznego, s. 46), w Archiwum MilZ PAN znajduje się zaś korespondencja, która dowodzi ich wieloletniej osobistej znajomości, jak np. datowany na 24 kwietnia 1968 r. list od Spychalskiego z serdecznymi życzeniami dla Feliksiaka. 
pozwoliły na szybkie rozpoczęcie odbudowy gmachu Państwowego Muzeum Zoologicznego (od września 1944 r. do marca 1945 r. Spychalski był prezydentem miasta Warszawy ${ }^{26}$ ). Jak oceniał były kierownik Muzeum dr Janusz Domaniewski ${ }^{27}$ w sprawozdaniu z 20 marca 1945 r. skierowanym do Ministerstwa Oświaty ${ }^{28}$, do odbudowy instytucji niezbędne było ponad milion dolarów amerykańskich, a do jego przeprowadzki ${ }^{29}$ i początkowego funkcjonowania około miliona złotych ${ }^{30}$. Ostatecznie zlecone Biuru Odbudowy Stolicy prace pochłonęły 4,6 $\mathrm{mln}_{\text {złotych }}{ }^{31}$.

Poza odbudową majątku instytucji i zabezpieczeniem ocalałych zbiorów, szansą na zrekompensowanie ogromnych strat Państwowego Muzeum Zoologicznego było przejęcie zbiorów przyrodniczych i bibliotecznych z dawnych instytucji niemieckich pozostałych na ziemiach odzyskanych (jednocześnie ratując te kolekcje przed szabrem i całkowitym zniszczeniem). Stanisław Feliksiak wykorzystał tę szansę i dołączył do akcji prowadzonej przez Departament Likwidacyjny Ministerstwa Ziem Odzyskanych. Już 10 października 1945 r. otrzymał upoważnienie (nr N-2663/45N) Ministra Obrony marszałka Michała Roli-Żymierskiego do przejmowania zbiorów zoologicznych z Dolnego Śląska. Ten bardzo silny polityczny glejt Feliksiak wykorzystywał podczas następnych kilku lat, jak chociażby na XVII Zjeździe Delegatów Związku Muzeów w Polsce, który odbył się w Nieborowie we wrześniu 1946 r., gdzie domagał się tam przejmowania poniemieckich zbiorów na rzecz Państwowego Muzeum Zoologicznego ${ }^{32}$. Zaraz po wsparciu ze strony Ministerstwa Obrony, jeszcze w 1945 r. Feliksiak otrzymał glejty od kolejnych resortów. W sprawozdaniach z 30 sierpnia 1947 r. ${ }^{33}$ i 27 lutego 1952 r. ${ }^{34}$ Felisiak pisał, że w grudniu 1945 r. został upoważniony przez Ministerstwo Oświaty, Ministerstwo Administracji oraz Naczelne Dowództwo Wojska Polskiego do udziału w poszukiwaniach ocalałych zbiorów i przejmowania na rzecz Muzeum kolekcji, które uzna za wartościowe naukowo ${ }^{35}$.

Dalsze funkcjonowanie Państwowego Muzeum Zoologicznego wymagało nie tylko materialnej odbudowy instytucji, lecz też wizji przyszłego funkcjonowania oraz wielkich nakładów do realizacji tych celów. Plany zakładające odbudowę jednostki po odzyskaniu

26 Internetowy Polski Słownik Biograficzny, ipsb.nina.gov.pl/a/biografia/marian-spychalski [dostęp 6.03.2020].

27 Janusz Domaniewski (1891-1954), polski zoolog (ornitolog), inicjator powołania Narodowego Muzeum Przyrodniczego. Od 1931 r. doktor zoologii na Uniwersytecie Poznańskim. W latach 1935-1936 pełniący obowiązki kierownika Państwowego Muzeum Zoologicznego. Zob. J.B. Szczepski, Domaniewski Janusz, [w:] Słownik biologów polskich, s. 133-134.

28 AMilZ, sygn. A 1207, Sprawozdanie Janusza Domaniewskiego z dnia 20 marca 1945 roku sporządzone dla Ministerstwa Oświaty.

29 Domaniewski we wspomnianym wyżej sprawozdaniu przekonywał, że Warszawa jest po wojnie zbyt zniszczona i należy przenieść Państwowe Muzeum Zoologiczne do Krakowa jako najodpowiedniejszego dlań ośrodka uniwersyteckiego i naukowego. Deklarował przy tym gotowość do osobistego przeprowadzenia akcji przeniesienia. W rzeczonym czasie Domaniewski był profesorem Uniwersytetu im. Marii Curie-Skłodowskiej w Lublinie.

30 Jak podaje Mirosław Kłusek, Zasady przeliczania nakładów finansowych poniesionych w latach 1945-2010 przez Muzeum Pałacu w Wilanowie i jego poprzednika prawnego, „Annales. Etyka w życiu gospodarczym” t. 17, 2014, nr 2, s. 90, po wojnie po raz pierwszy ustalono kurs złotego polskiego do dolara amerykańskiego (USD) w dniu 23 sierpnia 1945 r., kształtując relację na poziomie 100 zł = 1 USD.

31 150-leciu Gabinetu Zoologicznego, s. 46.

32 A. Grzywacz-Dudek, Historia zbiorów ornitologicznych po 1945 roku, „Wiadomości Jelenia Góra” 17 X 2016 r., jelonka.com/historia-zbiorow-ornitologicznych-po-1945-roku-65515 [dostęp 9.03.2020].

33 AMilZ, sygn. A 2317, Sprawozdanie z podróży służbowej po Ziemiach Odzyskanych w celu zabezpieczenia zbiorów porzuconych odbytej w dniach od 5 sierpnia do 21 sierpnia $1947 \mathrm{r}$.

34 AMilZ, sygn. A 2317, Sprawozdanie dra Stanisława Feliksiaka z podróży służbowej do Cieplic w ramach delegacji od dnia 19 do 23 lutego $1952 \mathrm{r}$.

35 150-lecie Gabinetu Zoologicznego, s. 47. 
wolności tworzono jednak jeszcze w warunkach głębokiej okupacji, czego przykładem jest koncepcja Stanisława Feliksiaka z 27 lutego 1941 r. ${ }^{36}$, który snuł wizję budowy nowoczesnej, profesjonalnej jednostki naukowej skupionej przede wszystkim na badaniach, przy ograniczonej funkcji muzealno-wystawienniczej i popularyzatorskiej. Nie przewidziano wtedy, że po wojnie Polska znajdzie się w sowieckiej strefie wpływów, gdzie nowe porządki będą wprowadzane również w nauce.

Zmianom planowanym przez nowe władze sprzyjało to, że odbudowa zniszczonych instytucji naukowych możliwa była tylko przy silnym wsparciu finansowym i organizacyjnym administracji państwa. Ułatwiało to pozyskiwanie do współpracy naukowców, którzy za pomoc we wdrażaniu nowo modelu otrzymywali nie tylko znaczne wsparcie dla swoich jednostek naukowych, lecz także przepustkę do kariery zawodowej.

Jak zauważa Piotr Daszkiewicz, pierwszym z polskich biologów, który zdemaskował to zjawisko był Władysław Rydzewski, były pracownik Państwowego Muzeum Zoologicznego, który po wojnie ze względu na swój udział w Armii Krajowej, a potem Polskich Siłach Zbrojnych na Zachodzie nie mógł wrócić do Polski i przebywał na emigracji w Londynie ${ }^{37}$. Rydzewski opisał swoje obserwacje na łamach emigracyjnego paryskiego miesięcznika „Kultura”:

Doprowadzenie warsztatów pracy naukowej do stopnia używalności wymagało, obok ofiarnej pracy personelu, także i wielkich środków materialnych. Wśród ludzi, desygnowanych do objęcia władzy w Polsce, zbyt dużo było wytrawnych komunistów, znających Rosję i stosunek reżimu sowieckiego do nauki, by mogli oni niedoceniać roli nauki w państwie demokracji ludowej. W programie sowietyzacji Polski rola nauk biologicznych, zarówno w dziedzinie praktycznej, jak i ideologicznej, była niewątpliwie zawczasu uwzględniona [...] Wobec katastrofalnego stanu instytucji naukowych było rzeczą jasną, że albo reżim będzie musiał wyasygnować duże sumy na ich odbudowę, albo, w przeciwnym razie, musiano by zrezygnować z jakiejkolwiek poważniejszej pracy naukowej. Ponieważ, jak powiedziałem, rola nauki była przewidziana w "planie" - pieniądze zostały wyasygnowane ${ }^{38}$.

Funkcjonowanie naukowców w nowych warunkach nie wiązało się zatem jedynie z akceptacją władzy komunistycznej, ale i potencjalną gotowością do współpracy z aparatem państwa w zamian za wspomniane wyżej środki na odbudowę i działanie instytucji oraz możliwość rozwoju karier. Sowietyzacja zakładała bowiem, przynajmniej w teorii,

36 Stanisław Feliksiak widział przyszłe Muzeum przede wszystkim jako instytucję naukowo-badawczą, w mniejszym stopniu skupiając się na jej roli dydaktycznej i wystawienniczej. Tej funkcji miało służyć rozwijanie pracowni naukowych, sieci placówek terenowych, stacji badawczych, pracowni-zakładów o charakterze ogólnym i eksperymentalnym, w tym zakładów samodzielnych oraz hodowli. Funkcję muzealną sensu stricto miały pełnić zaś pracownie systematyczne-ogólne i znajdujące się przy nich zbiory. Feliksiak planował również stworzenie wystawy naukowej „mającej odzwierciedlać pełnię prac Instytutu” - co świadczy o tym, że ważne miało być nie tyle samo prezentowanie zbiorów zoologicznych, co skupienie się na działaniach i promocji samego Państwowego Instytutu Zoologicznego, czego skutkiem mogło być znaczne zawężenie grona odwiedzających, przede wszystkim do środowiska naukowego. Opracowanie Feliksiaka miało znacznie przy późniejszych pracach nad włączeniem Państwowego Muzeum Zoologicznego do Polskiej Akademii Nauk, kiedy posłużyło jako argument do odejścia od koncepcji reaktywacji Narodowego Muzeum Przyrodniczego na rzecz ograniczonego do roli badawczej Instytutu Zoologii PAN. Zob. AMilZ sygn. A 2242, Dokument z dnia 27 lutego 1941 roku sporządzony przez Stanisława Feliksiaka.

37 P. Daszkiewicz, L'Analyse du texte de Władysław Rydzewski sur la sovi tisation de la biologie au d but de la $p$ riode du communism en Pologne, "Organon” t. 48, 2016, s. 161-185.

38 W. Rydzewski, Nauki biologiczne, „Kultura” 1952, nr 3, s. 160. 
aktywne służenie władzy ludowej, rewizję dotychczasowej wiedzy oraz przyjęcie doktryny naukowej, której nie można podważać. W konsekwencji rosyjskie osiągnięcia naukowe bez względu na ich obiektywną wartość próbowano w początkach PRL przenosić i wdrażać. Jako przykład takich działań Rydzewski wskazuje teorie genetyczne Iwana Miczurina ${ }^{39}$ i Trofima Łysenki ${ }^{40}$, które na zachodzie były w toku dyskusji naukowej podważane, a w Związku Sowieckim uznano je za obowiązujące, nie dopuszczając dalszych badań, głosów krytycznych i prowadzenia debaty ${ }^{41}$.

Zaangażowanie części naukowców we wdrażanie w Polsce ludowej idei marksistowskich Rydzewski krytykował, widząc w nim zagrożenie dla jakości badań i nauki. Ubolewał, że powszechnym było cytowanie prac sowieckich autorów, powoływanie się na autorytety teoretyków komunizmu, a nawet na Stalina, jak również określanie w publikacjach przedwojennego dorobku zachodniej i polskiej nauki określeniem „burżuazyjno-kapitalistycznego"42. O ile te wstawki były łatwe do zauważenia i odseparowania od właściwych myśli autorów, o tyle gorsze były sytuacje, gdy autorzy włączali się w nurt bieżących poglądów, krytykowali wcześniejsze doktryny i odcinali się nawet od własnych prac, badań i ich wyników. Takie sytuacje Rydzewski oceniał jako bardzo trudne do rozpoznania, często bowiem nie sposób było stwierdzić, gdzie poglądy i wnioski badawcze zmieniały się naprawdę, a gdzie były jedynie wynikiem „kompromisu lub zwykłego oportunizmu i karierowiczostwa"43.

Argumentując dalej, dlaczego obawia się upolitycznienia i zideologizowania pracy rodzimych biologów, Rydzewski przywołał cytaty sowieckiej uczonej Olgi Lepieszyńskiej ${ }^{44}$, publikującej wtedy na łamach polskiego miesięcznika naukowego „Myśl współczesna”, które uznał za formę jaskrawą i groteskową, niemniej zaznaczając, że nie ocenia merytoryki prac uczonej ${ }^{45}$ :

Komórka, pomimo rozwoju morfologii i fizjologii, jak się okazuje wciąż jeszcze pozostaje czymś tajemniczym i nieznanym, wymaga jeszcze wielu wyjaśnień i pełnego poznania. Przyczyna tego stanu rzeczy tkwi w tym, że niektórzy z cytologów nie kierują się nauką Marksa. Engelsa. Lenina i Stalina ${ }^{46}$.

39 Iwan Władimirowicz Miczurin (1855-1935), rosyjski sadownik i hodowca znany z doświadczeń w krzyżowaniu gatunków roślin. Członek Akademii Nauk ZSRS. Twórca teorii genetycznych, tzw. „miczurinizmu”, wykorzystywanych w propagandzie Związku Sowieckiego, a obalonych przez późniejsze badania genetyczne. Zob. Encyklopedia PWN, encyklopedia.pwn.pl/haslo/Miczurin-Iwan [dostęp 9.03.2020].

40 Trofim Denisowicz Łysenko (1898-1976), sowiecki agrobiolog i agronom, twórca pseudonaukowej teorii dot. stadialnego rozwoju roślin i metod ich wdrażania w rolnictwie - tzw. „łysenkizmu”. Członek Akademii Nauk ZSRS. Negował prawo ewolucji Darwina, twierdząc, że gatunki nie konkurują, a współpracują. Jego teorie obowiązywały w doktrynie sowietów do lat sześćdziesiątych, kiedy okazały się nieskuteczne i błędne. Zob. Encyklopedia PWN, encyklopedia.pwn.pl/haslo/Lysenko-Trofim [dostęp 9.03.2020].

41 W. Rydzewski, op. cit., s. 154.

42 Ibid., s. 155

43 Ibid.

44 Jak podaje Zbigniew Kępa, „Nowa biologia” $w$ walce $z$ religią, „Zagadnienia filozoficzne w nauce”, t. 22, 1998, s. 66-67, Olga Borisowa Lepieszyńska (1871-1963) była wśród bardzo wpływowych autorów sowieckich, których prace były w Polsce od 1949 r. drukowane w wielkich nakładach i streszczane we wszystkich czasopismach przyrodniczych w ramach propagowania idei „nowej biologii”, zwanego inaczej „twórczym darwinizmem sowieckim".

45 W. Rydzewski, op. cit., s. 170.

46 O. Lepieszyńska, Rozwój procesów życiowych w okresie przed-komórkowym, „Myśl Współczesna” 1951, nr 3/4, s. 306. 
Pragnę wyrazić tutaj głęboką i serdeczną wdzięczność naszemu wielkiemu nauczycielowi, najgenialniejszemu ze wszystkich uczonych, wodzowi postępowej nauki, drogiemu towarzyszowi Stalinowi. Jego nauka, każda jego wypowiedź w sprawach nauki stawała się dla nas programem działania, była niezastąpionym oparciem w długiej i niełatwej walce o zwycięstwo zasad materialistycznych w nauce o komórce ${ }^{47}$.

Czas pokazał, że niebawem i niektórzy polscy badacze zaczęli używać języka w stylu Lepieszyńskiej w swoich publikacjach ${ }^{48}$. Zbigniew Kępa wskazuje, że momentem przełomowym, od kiedy wśród polskich przyrodników zaczęły pojawiać się informacje o marksistowskiej wizji wszechświata, ewolucji i „nowej biologii”, było zakończenie sesji Wszechzwiązkowej Akademii Nauk Rolniczych im. Lenina, która odbywała się w Moskwie od 31 lipca do 7 sierpnia 1948 r. $^{49}$ Inspirowane tym wydarzeniem polskie władze ludowe zorganizowały kolejne zjazdy przyrodników, które przygotowywały podwaliny Polskiej Akademii Nauk:

- III Zjazd Polskiego Towarzystwa Zoologicznego, w dniach 8-12 grudnia 1950 r. w Łodzi;

- Konferencję Biologiczną w Kuźnicach, w dniach od 27 grudnia 1950 r. do 13 stycznia 1951 r., zorganizowaną przez Ministerstwo Szkół Wyższych i Nauki oraz Zrzeszenie Przyrodników-Marksistów ${ }^{50}$, której celem było zapoznanie młodych naukowców z założeniami „nowej biologii", czyli z „twórczym darwinizmem sowieckim,

- I Kongres Nauki Polskiej, od 29 czerwca do 2 lipca 1951 r. w Warszawie, na którym powołano do życia PAN.

Już przed samymi zjazdami okazało się, że w zamian za możliwości kontynuowania pracy badawczej wielu naukowców jest gotowych do ustępstw i symbolicznego zerwania z przeszłością poprzez krytykę przedwojennych form i organizacji nauki z ostentacyjnym, choć nieszczerym i wymuszonym entuzjazmem, ciesząc się z tego, co rzekomo oferuje marksizm. Prof. Tadeusz Jaczewski, który po wojnie mocno zaangażował się w tworzenie PAN, tak przekonywał na Przedkongresowym Zjeździe Towarzystwa Zoologicznego w Łodzi:

Zoologię polską w tym okresie cechowały: bezplanowość badań, zależność tematyczna i metodologiczna od nauki obcej - zachodniej. Związany z tym kosmopolityzm, prawie zupełny brak kontaktów z nauką radziecką, a przede wszystkim brak właściwych podstaw ideologicznych [...] Zauważyć się daje [...] upadek zoologii systematycznej, niedostateczność badań nad fauną krajową, zaniedbywanie związku nauki z praktyką ${ }^{51}$.

47 Ibid., s. 328.

48 Zob. Studia nad łysenkizmem w polskiej biologii, red. P. Köhler, Kraków 2013.

49 Z. Kępa, op. cit., s. 4.

50 Zrzeszenie Przyrodników-Marksistów powstało z przekształcenia Koła Przyrodników-Marksistów, działającego pod patronatem ideologicznego komunistycznego miesięcznika "Nowe Drogi”. Jego liderami byli promujący „nową biologię" przyrodnicy działający w Polskiej Partii Robotniczej: Włodzimierz Michajłow, Kazimierz Petrusewicz i Jan Dembowski. Celem Zrzeszenia była „bezkompromisowa walka o ugruntowanie materialistycznego poglądu na świat oraz propagowanie podstaw materializmu dialektycznego w naukach przyrodniczych". W 1952 r. Zrzeszenie zostało włączone do działającego od 1875 r. Polskiego Towarzystwa Przyrodników im. M. Kopernika, które miało za cel szerokie propagowanie wiedzy przyrodniczej. Struktura i członkowie Zrzeszenia do dzisiaj pozostają do końca nieznani. Zob. ibid.

51 T. Jaczewski, Przedkongresowy Zjazd Towarzystwa Zoologicznego, „Życie Nauki” r. 6, 1951, nr 1/2, s. 86. 
W podobnym tonie Jaczewski przemawiał na zorganizowanej przez Ministerstwo Szkół Wyższych i Nauki oraz Zrzeszenie Przyrodników Marksistów Konferencji Biologicznej w Kuźnicach, odbywającej się na pół roku przez powołaniem Polskiej Akademii Nauk, gdzie przekonywał o słuszności wejścia nauk biologicznych na drogę upolitycznienia, a także o konieczności przezwyciężenia „kosmopolitycznych nawyków” oraz „burżuazyjnego obiektywizmu". Kolegom, którzy w swoich referatach i dyskusji wciąż powoływali się na autorytety z krajów kapitalistycznych, zalecał natomiast większy dystans i krytycyzm $^{52}$. Jaczewski chwalił natomiast te przypadki, gdzie taka refleksja i krytyka znalazły miejsce, nie bacząc na jej absurdalny kontekst:

Najtrudniejszą sprawą w nowym stylu zespołowej pracy naukowej jest niewątpliwie samokrytyka. Toteż wystąpień tego rodzaju nie było na konferencji dużo, a niektóre, jak przyznanie przez prof. J. Konorskiego błędności jego prób uzgadniania fizjologii pawłowskiej z idealistyczną fizjologią anglosaską, musiały być dopiero spowodowane przez wystąpienia dyskutantów, a w tym przypadku w szczególności przez wystąpienie prof. W.S. Rusinowa. Z tym większym uznaniem trzeba podkreślić szczerą, samokrytyczną postawę prof. T. Marchlewskiego i prof. E. Malinowskiego, którzy w swoim czasie byli czynnymi i wybitnymi pracownikami w dziedzinie genetyki mendlowsko-morganowskiej i mieli na tym polu poważny dorobek naukowy, a obecnie potrafili, nie tylko przyznać błędność ówczesnych swych założeń teoretycznych, ale również przestawić się w swej pracy na tory nowej genetyki miczurinowskiej ${ }^{53}$.

W tym kontekście nacisk na rewizję badań i poglądów badaczy Jaczewski uznawał za powiew wolności, a „wyzwalanie spod wpływów kosmopolitycznego ucisku naukowego” i „kapitalistycznego wyzysku” porównał wręcz do atmosfery wyzwolenia spod okupacji faszystowskiej ${ }^{54}$. Taką postawę potępiał Rydzewski, przestrzegając że nawet mała grupa lojalnych wobec nowej władzy, pozbawionych zasad moralnych naukowców może znacznie oddziaływać na resztę środowiska:

Wśród biologów polskich znalazło się dosłownie paru ludzi, którzy postawieni wysoko w hierarchii partyjnej, mogą wywierać i wywierają dominujący i kierujący wpływ na dzisiejsze losy biologii polskiej. Niebezpieczeństwo działalności tej nielicznej grupki leży w tym, że są to ludzie o wysokim stopniu inteligencji, gruntownym przygotowaniu fachowym, dużej wiedzy i - co należy podkreślić - pozbawieni całkowicie skrupułów natury moralnej czy patriotycznej55.

Rydzewskiego przerażała też wychwalana przez Jaczewskiego "swoboda oddechu”, jaka miała panować m.in. na Zjeździe w Kuźnicach. Widział w tym raczej narzuconą z góry atmosferę „upolityczniania nauki” oraz przekształcania biologów „burżuazyjnych” w naukowców „postępowych”. Tych postępowych uczonych miało cechować samokrytyka 
w pracy naukowej, ton uwielbienia w stosunku do „przodującej nauki radzieckiej” i czerpanie wszelkiego natchnienia i wzorów z tamtejszej nauki ${ }^{56}$.

Poza dawnym kapitalistycznym porządkiem, szczególnie jego tłem historycznym, ideologicznym i politycznym, biolodzy tacy jak Jaczewski negatywnie oceniali również dotychczasowe działania towarzystw naukowych. Jaczewski snuł przy tym nową wizję funkcjonowania towarzystw jako organizacji o charakterze naukowo-zawodowym, które nie prowadziłyby pracowni. W tym zamyśle zebrania Polskiego Towarzystwa Zoologicznego stałyby się szkołą krytyki i samokrytyki oraz upolitycznienia zoologów i miałyby „przełamywać tradycyjne przeżytki wyobrażeń o nietykalności naukowej specjalistów i wyrabiać typ postępowego, rzetelnego, socjalistycznego pracownika naukowego" 57.

Dawne jednostki naukowe krytykował również, odkrywając ich rzekomy niesamodzielny charakter i czerpanie ze złych zachodnich wzorców, Kazimierz Petrusewicz ${ }^{58}$, profesor biologii z Uniwersytetu Warszawskiego, a jednocześnie kierownik Wydziału Nauki i Szkolnictwa Wyższego KC PZPR:

Podczas prac kongresowych zgromadzono wiele ciekawego materiału odnośnie objawów kosmopolityzmu w nauce Polski międzywojennej. Pokazano przykłady czołobitności wobec wszelkich wyników nauki „zachodniej”, nawet wątpliwych i błędnych [...] Kierunki i szkoły, ogłaszane za oryginalne polskie jakże często okazywały się zniekształconym odbiciem koncepcji przeniesionych na nasz grunt z burżuazyjnej nauki zachodu. Tak było na przykład w przypadku rzekomo „oryginalnej” Iwowskiej szkoły antropologicznej, w istocie zaś zrodzonej na gruncie hołdowania amerykańskiemu morganizmowi i niemieckiemu rasizmowi ${ }^{59}$.

Na tym tle, w opinii uczestników Zjazdu, wyróżniały się dobrze działające przedwojenne jednostki, do których należały szkoły utworzone przez Konstantego Janickiego ${ }^{60}$ i Kazimierza Białaszewicza ${ }^{61}$ z Uniwersytetu Warszawskiego, Henryka Hoyera ${ }^{62}$ i Emila Godlewskiego (młodszego) ${ }^{63}$ z Uniwersytetu Jagiellońskiego, Stacja Hydrobiologiczna na Wi-

56 Ibid., s. 167.

57 T. Jaczewski, Przedkongresowy Zjazd, s. 89-90.

58 Kazimierz Petrusewicz (1906-1982) polski ekolog, profesor Uniwersytetu Warszawskiego, działacz komunistyczny, w latach 1949-1952 kierownik Wydziału Nauki i Szkolnictwa Wyższego KC PZPR, kierownik Instytutu Ekologii Polskiej PAN. Zob., Instytut Nenckiego, mikolajki.nencki.gov.pl/ludzie/kazimierz-petrusewicz, [dostęp 8.03.2020].

59 K. Petrusewicz, Pierwszy Kongres Nauki Polskiej, „Nowe Drogi” 1951, nr 3, s. 83-84.

60 Konstanty Janicki (1876-1932) polski zoolog, parazytolog i cytolog. Twórca polskiej szkoły parazytologicznej, profesor na Uniwersytecie Warszawskim. Doktorat uzyskał w 1906 r.. W latach 1911-1919 pracownik Instytutu Zoologicznego w Bazylei. Członek Akademii Umiejętności, Polskiej Akademii Umiejętności i Towarzystwa Naukowego Warszawskiego. Zob. L. Pawłowski, Janicki Konstanty Stanisław (1876-1932), [w:] Słownik biologów polskich, s. 224-225.

61 Kazimierz Juliusz Białaszewicz (1882-1943) polski biolog, od 1920 r. profesor Uniwersytetu Warszawskiego, kierownik Katedry Fizjologii Zwierząt, członek Polskiej Akademii Umiejętności, dyrektor Instytutu Nenckiego. Zob. Instytut Nenckiego, nencki.gov.pl/historia [dostęp 8.03.2020].

62 Henryk Ferdynand Hoyer (1864-1947), polski zoolog, anatom, twórca polskiej szkoły anatomii porównawczej, profesor na Uniwersytecie Jagiellońskim, później rektor tamże, wiceprezes Polskiej Akademii Umiejętności. Zob. S. Feliksiak, Hoyer Henryk Ferdynand, [w:] Słownik biologów polskich, s. 211-212.

63 Emil Godlewski (młodszy) (1875-1944), polski biolog, lekarz, profesor embriologii, członek Polskiej Akademii Umiejętności i Towarzystwa Naukowego Warszawskiego. Zob. Katedra Historii Medycyny Uniwersytetu Jagiellońskiego Collegium Medicum, khm.cm-uj.krakow.pl/historia-wydzialow-lekarskich-w-polsce, [dostęp 9.03.2020]. 
grach oraz Państwowe Muzeum Zoologiczne w Warszawie ${ }^{64}$. W tym ostatnim Jaczewski pracował od 1924 roku, pełniąc przejściowo funkcję kierownika, zatem pochwała macierzystej jednostki nie może dziwić.

O dotychczasowej organizacji systemu nauki poza Jaczewskim wypowiadali się również wspomniany wcześniej Petrusiewicz oraz Włodzimierz Michajłow65 ${ }^{65}$, profesor zoologii ze Szkoły Głównej Gospodarstwa Wiejskiego, krytykując międzywojenne ciążenie i związki nauki z krajami kapitalistycznymi, na których mieli ślepo wzorować się Polacy ${ }^{66}$. Ponadto krytykowali działanie Polskiej Akademii Umiejętności w Krakowie jako niespełniającej właściwie swojej roli:

Liczne towarzystwa naukowe, spośród których większość - mimo najlepszych chęci - wiodła suchotniczy żywot, nie mogły zmienić tego stanu rzeczy. Nie odegrała roli koordynatora badań, wytyczającego kierunki badawcze Polska Akademia Umiejętności ${ }^{67}$.

W przypadku tego towarzystwa krytyka nie była to jednak dominująca, jak bowiem zauważa Piotr Hübner, członkowie zarówno Polskiej Akademii Umiejętności w Krakowie, jak i Towarzystwa Naukowego Warszawskiego zostali uhonorowani podczas sesji I Kongresu Nauki Polskiej i stali się aktywną stroną rozmów o powołaniu PAN ${ }^{68}$.

W wypowiedziach na zjazdach naukowych pojawiała się też krytyka merytoryczna, punktująca przedwojenny brak środków na badania naukowe, chaos w planowaniu i strukturze instytucji naukowych i słabe powiązanie badań naukowych z interesem ekonomicznym państwa. Problemy te były obiektywne i pisał też o nich Rydzewski, dobrze pamiętający przedwojenne fatalne warunki lokalowe oraz materialne permanentnie niedofinansowanego Państwowego Muzeum Zoologicznego. Mając to na uwadze, Rydzewski wiązał pewne nadzieje związane z zapowiedziami Kongresu Nauki i chwalił szeroką dyskusję o dotychczasowych problemach - szczególnie postulat poprawy planowania badań naukowych, poprawienia jakości pracy zespołowej, wzmocnienia popularyzacji wiedzy i lepszego wykorzystywania nauki do rozwoju gospodarczego kraju ${ }^{69}$. Niemniej bez względu na panujący ustrój rozwiązaniem tych problemów były przede wszystkim odpowiednie środki finansowe przeznaczane na naukę. Przyznawali to wprost również twórcy Polskiej Akademii Nauk, tacy jak prof. Jan Dembowski70, przewodniczący Komitetu Wykonawczego I Kongresu Nauki Polskiej, podkreślając, że możliwości materialne Polski ludowej też są ograniczone:

64 W. Rydzewski, op. cit., s. 157.

65 Włodzimierz Michajłow (1905-1994), polski zoolog, parazytolog, profesor na Katedrze Zoologii Szkoły Głównej Gospodarstwa Wiejskiego, kierownik Instytutu Parazytologii PAN, po 1959 r. wiceminister Nauki i Szkolnictwa Wyższego. Zob. Encyklopedia PWN, encyklopedia.pwn.pl/haslo/Michajlow-Wlodzimierz;3940438.html [dostęp 16.03.2020].

66 K. Petrusewicz, W. Michajłow, O twórczy rozwój nauk biologicznych w Polsce, „Nowe Drogi” 1951, nr 1 s. 225.

67 Ibid., s. 227.

68 P. Hübner, Polityka naukowa w Polsce w latach 1944-1953. Geneza systemu, t. 1, Warszawa 1992, s. 778.

69 W. Rydzewski, op. cit., s. 172.

70 Jan Bohdan Dembowski (1889-1963), polski biolog (zoopsycholog, etolog). W latach 1952-1957 prezes Polskiej Akademii Nauk, w latach 1947-1961 dyrektor Instytutu Biologii Doświadczalnej w Warszawie, w latach 1952-1960 profesor Uniwersytetu Warszawskiego, marszałek Sejmu PRL I kadencji. Zob. Encyklopedia PWN encyklopedia.pwn.pl/haslo/Dembowski-Jan-Bohdan [dostęp 10.03.2020]. 
Kraj nasz nie jest dość bogatym, by mógł zapewnić wszystkim swym pracownikom naukowym najlepsze warunki pracy [...]. Te najlepsze warunki pracy można zapewnić tylko nielicznej, wybranej grupie uczonych, o których wiemy na pewno, że potrafią warunki te w pełni wyzyskać [...]. Uczeni ci powinni stać się awangardą nauki w kraju, najwyższą decydującą instancją w sprawach wiedzy, mózgiem kraju¹.

Właśnie ta awangarda zamierzała tworzyć i rozwijać nową instytucję naukowo-badawczą, jaką miała być Polska Akademia Nauk, którą oficjalnie powołano 2 lipca $1951 \mathrm{r}$. podczas I Kongresu Nauki Polskiej, obradującego w auli głównej Politechniki Warszawskiej. Ustawę o Polskiej Akademii Nauk przyjęto kilka miesięcy później, 30 października 1951 r. $^{72}$. Chociaż na zjazdach przedkongresowych nie brakowało słów krytyki na temat działalności przedwojennych towarzystw naukowych, władze krajowe zdecydowały, że PAN powstanie na bazie Polskiej Akademii Umiejętności w Krakowie i Towarzystwa Naukowego Warszawskiego, co w Ustawie znalazło wyraz w odwołaniu się do ich dziedzictwa jako ważnych ośrodków polskiego życia naukowego:

Art. 1. I. W celu zapewnienia nauce polskiej warunków wszechstronnego rozwoju i pełnego rozkwitu oraz nadania badaniom naukowym kierunku, odpowiadającego istotnym potrzebom Narodu, w oparciu o postępowe tradycje nauki, jako też o najlepsze osiągnięcia i doświadczenia wszystkich działających dotychczas instytucji i zrzeszeń naukowych, w szczególności Polskiej Akademii Umiejętności i Towarzystwa Naukowego Warszawskiego - powołuje się Polską Akademię Nauk.

Czerpanie z dziedzictwa tych organizacji miało też wymiar materialny i mniej dla nich szczęśliwy, albowiem uchwałami Rady Ministrów z 1952 r.73 PAN przejęła agendy, majątki, personel etatowy i członków Towarzystwa Naukowego Warszawskiego ${ }^{74}$ i Polskiej Akademii Umiejętności w Krakowie ${ }^{75}$, jednocześnie nie dokonując formalnej likwidacji obu towarzystw ${ }^{76}$.

71 W przeddzień powstania Polskiej Akademii Nauk, „Życie Nauki” r. 6, 1951, nr 1/2, s. s. 76 (cytat J. Dembowskiego przywołany w artykule nieznanego autora).

72 Ustawa z dnia 30 października 1951 r. o Polskiej Akademii Nauk, Dziennik Ustaw 1951 nr 57 poz. 391.

7313 grudnia 1952 r. Rada Ministrów przyjęła Uchwałę nr 1149/52 w sprawie przekazania Polskiej Akademii Nauk urządzeń i składników majątkowych Towarzystwa Naukowego Warszawskiego, zgodnie z którą działalność TNW ustała 31 grudnia 1952 r. Od 1 stycznia 1953 r. majątek TNW stał się częścią PAN, do której przeszli też z etatami pracownicy Towarzystwa. 20 grudnia 1952 r. Rada Ministrów przyjęła Uchwałę Nr 1167/52 w sprawie przekazania Polskiej Akademii Nauk urządzeń i składników majątkowych Polskiej Akademii Umiejętności, która kończyła działalność organizacji, ale tylko w tych obszarach, które zostały przejęte przez PAN. Zob. P. Hübner, op. cit., s. 787.

74 Po utracie majątku na rzecz PAN TNW zaprzestało działalności do 1981 r., kiedy to nastąpiła jego reaktywacja, zob. Z. Mikulski, Z życia nauki i z życia Towarzystwa: Jubileusz stulecia Towarzystwa Naukowego Warszawskiego (1907-2007): 100 lat Towarzystwa Naukowego Warszawskiego (1907-2007), „Rocznik Towarzystwa Naukowego Warszawskiego" t. 70, 2007, s. 12.

75 PAU pozostawała, w przeciwieństwie do TNW, w okresie przejściowym w sprawie przyjęcia do PAN jej personelu, zabiegała bowiem o pewną niezależność i luźniejsze związki ośrodka krakowskiego z centralą w Warszawie. Sprawę rozwiązało przyjęcie członków PAU w poczet Prezydium PAN. Zob. P. Hübner, op. cit., s. 778-779, 784-785. W latach 1956/1957 oraz 1980/1981 były nieudane próby reaktywacji PAU. Działalność udało się podjąć po 1989 r. Zob. Portal Polskiej Akademii Umiejętności, pau.krakow.pl/index.php/pl/akademia/historia [dostęp 15.04.2020].

76 P. Hübner, op. cit., s. 778-779, zwraca uwagę, że decydenci i przedstawiciele towarzystw naukowych w wystąpieniach i dokumentach unikali słowa „likwidacja”, stawiając na metodę „powolnego więdnięcia”. O PAU mówiono, że jej działalność ulega „treściowej likwidacji”, TNW miało zaś „zakończyć swoją działalność jako samodzielna instytucja naukowa". 
Polska Akademia Nauk z jednej strony odwoływała się do dziedzictwa towarzystw naukowych, jawiąc się jako „towarzystwo państwowe”, z drugiej jej forma nie pozostawiała wątpliwości, że na wzór Moskiewskiej Akademii Nauk miała być najwyższą w hierarchii jednostką naukową w kraju i rządową instytucją centralną, pozwalającą na lepszą kontrolę władz państwowych nad działalnością naukową. Akademia miała prowadzić prace badawcze, ale też koordynować i planować pracę poszczególnych naukowców. Jako jednostka elitarna miała grupować tylko wybranych uczonych.

W ocenie Rydzewskiego charakter roboczy PAN i jej zadania organizacyjne z założenia wskazywały, że jej członkami będą naukowcy lojalni wobec aparatu państwa i gwarantujący rozwój w pożądanym przez władzę kierunku"7. Pomimo tego przy całej atmosferze i formach narzuconych przez komunistów Rydzewski był wśród naukowców którzy wierzyli, że nauka sama w sobie przetrwa i zwycięży swoją siłą merytoryczną, „bowiem obiektywne zdobycze biologii zachowają swoją wartość bez względu na politykę"78. Uważał przy tym, że między komunistyczną teorią i ideologią a praktyką i realnym życiem jest przepaść i wiele z narzucanych poglądów pozostanie tylko frazesem czy manierą, bez znaczącego wpływu na naukę - co zważywszy na późniejsza małą rolę „nowej biologii” i „twórczego darwinizmu" okazało się prawdą. Jednak, co najważniejsze, Rydzewski wierzył, że komunizm jest tylko okresem przejściowym i niebawem Polska odzyska suwerenność ${ }^{79}$. Za największe zagrożenie związane z nowym systemem nauki Rydzewski uważał kształcenie młodych kadr naukowców. O ile spokojniejszy był o „starą gwardię”, wychowaną jeszcze w wolnej Polsce, o tyle obawiał się, że młodzi naukowcy wpadną w pułapkę koniunkturalizmu, odcinania od nauki Zachodu i wtłaczania w ideologię socjalizmu. Przede wszystkim zagrożenie widział w sposobie kształcenia nowych kadr, które wyrosną w nowym systemie, odcięte od świata zachodniego, czerpiąc jedynie z marksistowskiej teorii nauki. Ich nadzieją w ocenie Rydzewskiego pozostać mieli jedynie nauczyciele wychowani w tradycji dawnej nauki ${ }^{80}$.

Wyraźnym sygnałem potwierdzającym niektóre obawy Rydzewskiego było zebranie pracowników naukowych Państwowego Muzeum Zoologicznego, które odbyło się w gmachu przy ul. Wilczej 30 stycznia 1953 r. Spotkanie dotyczyło planów naukowych na 1953 r. W harmonogramie obrad znalazł się punkt 4 - „Sprawa stypendiów”, któremu w sprawozdaniu z zebrania poświęcono następująca notatkę:

ad. 4. Pięciu asystentów naszej Instytucji złożyło indywidualne podania do PAN o stypendia na prace naukowe. W związku z powyższym ob. Dyrektor wyjaśnił, że Muzeum nie otrzymało w swoim czasie żadnego pisma od Akademii w sprawie składania wniosków o stypendia, a pracownicy przeprowadzili starania z konieczności indywidualnie. Obecnie Akademia jednak zwróciła się do Instytucji z prośbą o występowanie opinii o poszczególnych petentach. Muzeum nie mogło prowadzić sprawy uzyskania stypendiów dla swych pracowników ze względów formalnych, ponieważ załatwić mógł je jedynie Instytut Zoologiczny. Na przyszłość Instytucja nie będzie pomijana przy wystawianiu kandydatów na stypendia naukowe ${ }^{81}$. 
"Sprawa stypendiów" pokazuje, jak ówczesne władze PAN, będące dysponentem środków finansowych przeznaczonych na naukę, traktowały instytucje naukowe i w jaki sposób pozyskiwały młode kadry.

Od końca 1951 r. rozpoczęto prace nad powołaniem Instytutu Zoologicznego PAN, o czym wiemy z anonimowej notatki z 20 listopada 1951 r., skierowanej do Michajłowa ${ }^{82}$. Autorem notatki był prawdopodobnie Jaczewski. Uczony ten, jako przewodniczący Komitetu Zoologicznego PAN, brał aktywny udział w pracach nad powołaniem Instytutu Zoologicznego PAN ${ }^{83}$. Zgodnie z zamysłem autora notatki w strukturę tego Instytutu miały zostać włączone następujące jednostki:

- dotychczasowe Państwowe Muzeum Zoologiczne w formie ograniczonej do części muzealnej, tj. pracowni muzealnej, magazynu materiałów zoologicznych i działu wystawowego,

- przekształcona i zreorganizowana biblioteka Państwowego Muzeum Zoologicznego, która w nowej formie, jako Biblioteka Zoologiczna PAN, miałaby stać się centralną polską biblioteką zoologiczną,

- przekształcone i rozbudowane archiwum Państwowego Muzeum Zoologicznego, które stałoby się Ośrodkiem Dokumentacji Zoologicznej PAN,

- stacja ornitologiczna Państwowego Muzeum Zoologicznego, która po utworzeniu właściwej placówki terenowej, stałaby się Stacją Ornitologiczną PAN,

- nowa placówka terenowo-laboratoryjna (wg projektu dr. Stanisława Adamczewskiego) jako Pracownia Biologii Zwierząt PAN.

Dodatkowo w ramach Instytutu rozważano stworzenie Pracowni Parazytologicznej PAN oraz redakcji wydawnictw zoologicznych PAN.

Nowo powołany Instytut miał przejąć i włączyć w swoje struktury jako działy zoologiczne Muzea Przyrodnicze PAN w Krakowie, Poznaniu i Łodzi, jak również koordynować pracę instytutów uczelnianych:

- Międzyuczelnianego Instytutu Zoologicznego w Warszawie,

- Instytutu Zoologicznego Uniwersytetu Jagiellońskiego w Krakowie,

- Instytutu Zoologicznego Uniwersytetu Poznańskiego,

- Instytut Zoologicznego Uniwersytetu Marii Curie-Skłodowskiej w Lublinie,

- Instytutu Zoologicznego Uniwersytetu Łódzkiego,

- Instytutu Zoologicznego Uniwersytetu Mikołaja Kopernika w Toruniu,

- Instytutu Zoologicznego Uniwersytetu Wrocławskiego.

Poprzez Komitet Zoologiczny PAN Instytut Zoologiczny PAN nawiązałby ścisłą współpracę z następującymi instytucjami:

- Instytutem im. Nenckiego, szczególnie z Zakładem Biologii Ogólnej, Zakładem Ekologii Zwierząt i ze Stacją Hydrobiologiczną,

- Morskim Instytutem Rybackim,

- Inspektoratem Nadzoru nad Ogrodami Zoologicznymi.

Zawarta w dokumencie krótka wizja funkcjonowania Instytutu Zoologicznego PAN opiera się właściwie na dostosowaniu jednostek działających dotychczas w ramach Państwowego Muzeum Zoologicznego do struktury Polskiej Akademii Nauk, nadaniu im rangi 
centralnych - ogólnokrajowych, merytorycznemu podporządkowaniu Instytutowi, tak jak w przypadku kilku innych muzeów przyrodniczych, a także koordynacji oraz współpracy nowo powołanej placówki PAN z instytutami uczelnianymi bądź samodzielnymi instytucjami naukowymi. Zadania te opisane zostały bardzo ogólnie i wielokrotnie pojawiają się dopiski o potrzebie dalszej dyskusji, przemyślenia czy też dokładnego określenia danych kwestii. Dokument nie mówi nic o strukturze nowego Instytutu, jego budżecie, kadrach, siedzibie, co zostało doprecyzowane dopiero w późniejszym okresie. Notatka musiała powstać raczej w pośpiechu, aby udowodnić, że autor jest gotowy do współpracy z Akademią i pomoże włączyć jednostkę w jej struktury.

Późniejsze prace nad powołaniem Instytutu Zoologicznego PAN były bardziej konkretne, albowiem 4 września 1952 r. Jaczewski skierował do Sekretariatu Wydziału II PAN pismo ${ }^{84}$, w którym stosownie do ustnego polecenia dokonał przeglądu preliminarzy budżetów na 1953 r.: Państwowego Muzeum Zoologicznego w Warszawie, Muzeum Przyrodniczego w Łodzi i Muzeum Przyrodniczego w Poznaniu, pod kątem planu połączenia ich $w$ jeden instytut. Jaczewski, zaznaczając, że nie jest wprowadzony $w$ bieżącą pracę instytucji w Łodzi i Poznaniu, wniósł jedynie po kilka drobnych uwag do każdego z analizowanych budżetów - przede wszystkim poprosił o dodatkowe wyjaśnienia i uzasadnienie do zakupu różnych czasopism. Zauważył też pewne zawyżone sumy w limicie budowlanym i planie zakupu materiałów biurowych. W podsumowaniu uznał, że budżety placówek, jak i ich zasoby kadrowe po odpowiedniej reorganizacji i racjonalizacji pozwolą na stworzenie Instytutu Zoologicznego PAN już w pierwszym etapie jego organizacji. Na końcu Jaczewski, powołując się na dyskusję na zebraniu Komitetu Zoologicznego PAN dnia 10 czerwca 1952 r., podkreślił, że Instytut będzie potrzebował dodatkowo etatów: dyrektora, sekretarza i kierowcy, a także przydziału samochodu osobowego.

Finał prac nad nową centralną jednostką zoologiczną nastąpił 26 września 1952 r., kiedy to Uchwałą nr 830 Rady Ministrów ${ }^{85}$ powołano Instytut Zoologiczny Polskiej Akademii Nauk, powstały z połączenia Państwowego Muzeum Zoologicznego w Warszawie, Muzeum Zoologicznego w Poznaniu i Muzeum Przyrodniczego w Łodzi" ${ }^{86}$. W grudniu 1953 r. do Instytutu Zoologicznego włączono także Muzeum Przyrodnicze Polskiej Akademii Umiejętności w Krakowie. Instytut Zoologiczny był zgodnie z Uchwałą Rady Ministrów samodzielną placówką naukową Akademii (§ 2), posiadającą osobowość prawną (§3). Centralą Instytutu stała się dotychczasowa siedziba Państwowego Muzeum Zoologicznego przy ul. Wilczej 64.

Pierwszym dyrektorem Instytutu Zoologicznego został Jaczewski, co można odczytywać jako nagrodę za jego duże zaangażowanie w tworzenie PAN. Dotychczasowy dyrektor Państwowego Muzeum Zoologicznego, Stanisław Feliksiak, zapewne nie był dalej

84 AMilZ, sygn. A 687, Pismo prof. Tadeusz Jaczewskiego z dnia 4 września 1952 roku skierowane do Sekretariatu Wydziału II Polskiej Akademii Nauk.

85 Uchwała nr 830 Rady Ministrów z dnia 26 września 1952 r. w sprawie przekazania Polskiej Akademii Nauk Państwowego Muzeum Zoologicznego w Warszawie, Muzeum Przyrodniczego w Łodzi i Muzeum Przyrodniczego w Poznaniu oraz powołania Instytutu Zoologicznego Polskiej Akademii Nauk, Monitor Polski 1952, nr 88, poz. 1369.

86 Muzeum Przyrodnicze w Łodzi było oddziałem zamiejscowym Instytutu Zoologicznego PAN jedynie do roku 1962 kiedy zostało włączone do Uniwersytetu Łódzkiego w ramach Katedry Ewolucjonizmu, zob. Muzea uczelniane. Katalog, red. H. Kowalski, M. Grassman, M. Bukowski, J. Ślaga, M. Piszczatowska, Warszawa 2017, s. 201. 
brany pod uwagę na tym stanowisku, jak bowiem zauważają Piotr Daszkiewicz i Dariusz Iwan pomimo ogromnego dorobku naukowego i wielkich zasług w ratowanie i odbudowę Muzeum i jego kolekcji był zbyt mocno zaangażowany w działalność Armii Krajowej i konspirację ${ }^{87}$. Zakrawa to na ironię, jeżeli spojrzymy na największą zmianę kierunkową, jaka realnie nastąpiła po powołaniu Instytutu Zoologicznego PAN: o ile funkcjonujący przez dziesięciolecia Gabinet Zoologiczny i kontynuujące go muzea za najważniejsze zadanie stawiały sobie pozyskiwanie i opracowywanie okazów przyrodniczych, to Instytut Zoologiczny od początku za priorytet stawiał sobie prowadzenie badań naukowych. Pierwszym, który postulował zmianę w tym kierunku. był właśnie Feliksiak we wspomnianej wcześniej koncepcji datowanej na 27 lutego $1941 \mathrm{r}$.

\section{Bibliografia}

\section{Źródła archiwalne}

Archiwum Muzeum i Instytutu Zoologii PAN [AMilZ]:

sygn. A 144, Projekt Budżetu Państwowego Muzeum Zoologicznego od 1 kwietnia 1936 do 31 marca 1937;

sygn. A 166, J. Domaniewski, Sprawozdanie ze strat w Bibljotece spowodowanych pożarem Państwowego Muzeum Zoologicznego w Warszawie w dniu 1-ym października 1935 roku;

sygn. A 687, Notatka z dnia 20 listopada 1951 roku dla prof. Włodzimierza Michajłowa; Pismo prof. Tadeusz Jaczewskiego z dnia 4 września 1952 roku skierowane do Sekretariatu Wydziału II Polskiej Akademii Nauk.

sygn. A. 1207, Sprawozdanie Janusza Domaniewskiego z dnia 20 marca 1945 roku sporządzone dla Ministerstwa Oświaty;

sygn. A 2256, Memoriał Stanisława Feliksiaka w sprawie Państwowego Muzeum Zoologicznego $w$ Warszawie sporządzony 25 lutego 1945 roku w Lublinie;

sygn. A 2257, K. Tarwid, Zbiory przyrodnicze $i$ ich losy $w$ Warszawie, s. 2. Dokument powojenny, niedatowany;

sygn. A 2317, Sprawozdanie z podróży służbowej po Ziemiach Odzyskanych w celu zabezpieczenia zbiorów porzuconych odbytej w dniach od 5 sierpnia do 21 sierpnia 1947 r.; Sprawozdanie dra Stanisława Feliksiaka z podróży służbowej do Cieplic w ramach delegacji od dnia 19 do 23 lutego 1952 r.;

sygn. A 2242, Dokument z dnia 27 lutego 1941 roku sporządzony przez Stanisława Feliksiaka;

sygn. A 2901, Sprawozdanie z zebrania pracowników naukowych PMZ w dniu 30.01.1953 r.

\section{Źródła drukowane}

Jaczewski, T., Konferencja Biologiczna w Kuźnicach, „Życie Nauki" r. 6, 1951, nr 3, s. 234-241. Jaczewski T., Przedkongresowy Zjazd Towarzystwa Zoologicznego, „Życie Nauki” r. 6, 1951 , nr 1/2, s. 85-91. 
Muzea uczelniane. Katalog, red. Kowalski H., Grassman M., Bukowski M., Ślaga J., Piszczatowska M., Warszawa 2017.

Lepieszyńska O., Rozwój procesów życiowych w okresie przed-komórkowym, „Myśl Współczesna" 1951, nr 3/4, s. 305-328.

Petrusewicz K., Michajłow, W., O twórczy rozwój nauk biologicznych w Polsce, "Nowe Drogi" 1951, nr 1 (25), s. 220-233.

Petrusewicz K., Pierwszy Kongres Nauki Polskiej, „Nowe Drogi” 1951, nr 3 (27), s. 75-89. Rozporządzenie Ministerstwa Wyznań Religijnych i Oświecenia Publicznego w sprawie utworzenia Narodowego Muzeum Przyrodniczego w Warszawie, Dziennik Urzędowy Ministerstwa Wyznań Religijnych i Oświecenia Publicznego Rzeczypospolitej Polskiej, Warszawa 1919 (rok II), nr 10/11 (z 1 listopada 1919 r.), poz. 6.

Rozporządzenie Prezydenta Rzeczpospolitej z dnia 29 lutego 1928 r. o Państwowem Muzeum Zoologicznem, Dziennik Ustaw 1928 poz. 207 i 208, nr 24.

Rydzewski W., Nauki biologiczne, „Kultura” 1952, nr 3, s. 154-176.

Uchwała nr 830 Rady Ministrów z dnia 26 września 1952 r. w sprawie przekazania Polskiej Akademii Nauk Państwowego Muzeum Zoologicznego w Warszawie, Muzeum Przyrodniczego w Łodzi i Muzeum Przyrodniczego w Poznaniu oraz powołania Instytutu Zoologicznego Polskiej Akademii Nauk, Monitor Polski 1952 nr 88 poz. 1369.

Uchwała nr 1149/52 Rady Ministrów z dnia 13 grudnia 1952 r. w sprawie przekazania Polskiej Akademii Nauk urządzeń i składników majątkowych Towarzystwa Naukowego Warszawskiego.

Uchwała nr 1167/52 Rady Ministrów z dnia 20 grudnia 1952 r. w sprawie przekazania Polskiej Akademii Nauk urządzeń i składników majątkowych Polskiej Akademii Umiejętności.

Ustawa z dnia 30 października 1951 r. o Polskiej Akademii Nauk, Dziennik Ustaw 1951 nr 57 poz. 391.

W przeddzień powstania Polskiej Akademii Nauk, „Życie Nauki” r. 6, 1951, nr 1/2, s. 76.

\section{Literatura przedmiotu}

150-lecie Gabinetu Zoologicznego w Warszawie (1818-1968), [w:] Memorabilia Zoologica, red. D. Iwan, Warszawa 2016.

Daszkiewicz P., Iwan D., Straty wojenne Państwowego Muzeum Zoologicznego - raport Stanisława Feliksiaka (1906-1992), „Pamięć i Sprawiedliwość. Pismo Instytutu Pamięci Narodowej" t. 27, 2016, s. 431-439.

Daszkiewicz P., L'Analyse du texte de Władysław Rydzewski sur la soviąisation de la biologie au dąout de la pąiode du communism en Pologne, „Organon” t. 48, 2016, s. 161-185.

Hübner P., Polityka naukowa w Polsce w latach 1944-1953. Geneza systemu, t. 1, Warszawa 1992.

Kępa Z., „Nowa biologia” w walce z religią, "Zagadnienia filozoficzne w nauce” t. 22, 1998 , s. 63-78.

Klee E., Das Personenlexikonzum Dritten Reich, Frankfurt nad Menem 2007.

Kłusek M., Zasady przeliczania nakładów finansowych poniesionych w latach 1945-2010 przez Muzeum Pałacu w Wilanowie $i$ jego poprzednika prawnego, „Annales. Etyka w życiu gospodarczym" t. 17, 2014, nr 2, s. 97-111.

Majewski T., Nauki biologiczne, [w:] Nauki ścisłe i przyrodnicze na Uniwersytecie Warszawskim, red. A.K. Wróblewski, Warszawa 2016, s. 51-192. 
Mikulski Z., Z życia nauki i z życia Towarzystwa: Jubileusz stulecia Towarzystwa Naukowego Warszawskiego (1907-2007): 100 lat Towarzystwa Naukowego Warszawskiego (1907-2007), „Rocznik Towarzystwa Naukowego Warszawskiego” t. 70, 2007, s. 9-14.

Słownik biologów polskich, red. S. Feliksiak, Warszawa 1987.

Studia nad tysenkizmem w polskiej biologii, red. P. Köhler, Kraków 2013.

Winiarska G., Adamczewski Stanisław Franciszek, [w:] Almanach Entomologów Polskich XX wieku, red. M. Bunalski, J.J. Lipa, J. Nawacki, Poznań 2001, s. 17-18.

\section{Strony internetowe}

Encyklopedia PWN, encyklopedia.pwn.pl [dostęp 9.03.2020].

Instytut Nenckiego, nencki.gov.pl [dostęp 8.03.2020].

Grzywacz-Dudek, A., Historia zbiorów ornitologicznych po 1945 roku, „Wiadomości Jelenia Góra", 17 października 2016 r., www.jelonka.com/historia-zbiorow-ornitologicznychpo-1945-roku-65515 [dostęp 9.03.2020].

Internetowy Polski Słownik Biograficzny, ipsb.nina.gov.pl [dostęp 3.03.2020].

Katedra Historii Medycyny Uniwersytetu Jagiellońskiego Collegium Medicum, khm.cm-uj. krakow.pl [dostęp 9.03.2020].

Muzeum Powstania Warszawskiego, Powstańcze Biogramy, 1944.pl [dostęp 15.03.2020]. Polska Akademia Nauk, instytucja.pan.pl [dostęp 20.02.2020].

Polska Akademia Umiejętności, pau.krakow.pl [dostęp 15.04.2020].

mgr Wojciech Zabłocki, absolwent Wydziału Historycznego UW. Zajmuje się historią polskich badań zoologicznych, szczególnie ideą, rozwojem, okolicznościami upadku i próbami reaktywacji Narodowego Muzeum Przyrodniczego.

e-mail: wjzablocki@wp.pl

Data zgłoszenia artykułu: 16 marca 2020

Data przyjęcia do druku: 30 kwietnia 2020 